\title{
Comparative biological and antiquorum activity of extracts of lamiaceae plants, grown in the Russian Federation
}

\author{
Galimzhan Duskaev ${ }^{1,{ }^{*}, \text { Dmitry Deryabin }}{ }^{1}$, Dianna Kosyan ${ }^{1}$, Elena Rusakova ${ }^{1}$, Kseniya \\ Inchagova $a^{1}$, and Olga Kvan ${ }^{1}$ \\ ${ }^{1}$ Federal Research Center of Biological Systems and Agrotechnologies of the Russian Academy of \\ Sciences, Yanvarya St., 29, 9, Orenburg, 460000, Russia
}

\begin{abstract}
The purpose of this study was to assess the biological activity and antiquorum activity of extracts of Lamiaceae plants. Material and methods. Extracts of 4 medicinal plants of the Lamiáceae were used as test substances. Bioluminescent analysis were used on the model Escherichia coli MG1655 and antiquorum activity of medicinal plant extracts - on the model Chromobacterium violaceum ATCC 31532. Result. An analysis of the bioluminescent testing of Mentha piperita leaf aqueous extract showed no toxic effect throughout the entire record period over the entire concentration range. Low concentrations of analyte $(0.625 \mathrm{mg} / \mathrm{ml}-0.0097$ $\mathrm{mg} / \mathrm{ml}$ ) cause a slight induction of lux-operon. Sālvia officinālis extract showed a slight antibacterial effect on the tested strain $($ EC50 $=10 \mathrm{mg} / \mathrm{ml})$. The effect is achieved after 50-60 minutes of contact of microbial cells with components of Sālvia officinālis extract and persists until the end of the analyzed period of time (180 minutes). Extract of Oríganum vulgáre showed a decrease in the level of luminescence by $30 \%$ when the analyte was exposed to a concentration of $10 \mathrm{mg} / \mathrm{ml}$. The extract of Thýmus serpýllum showed a pronounced antibacterial effect on the test organism, with a maximum concentration of $10 \mathrm{mg} / \mathrm{ml}$, a $50 \%$ inhibition of luminescence is observed. All the tested compounds in subinhibitory concentrations suppressed the quorum-dependent biosynthesis of violacein.
\end{abstract}

\section{Introduction}

The ban on the use of antibiotics in animal husbandry has contributed to a more active search for new alternative substances. The urgency of the problem is determined by the need to replace feed antibiotics in the diets of farm animals with new drugs and to create highly effective feeding systems based on them. Many medicinal plants have antibacterial activity, and are actively used in animal nutrition, including for treatment. For example, plant extracts containing tannins and essential oils are effective against Clostridium perfringens, which causes necrotic enteritis in poultry [1]. A wide variety of herbs have been used in poultry farming for potential use as an alternative to antibiotics [2].

\footnotetext{
*Corresponding author: gduskaev@mail.ru
} 
The mechanism of action of plant extracts is poorly known, but depends on the composition of active substances in the extract used. The positive effect is due to their antimicrobial and antioxidant properties, including against various pathogenic bacteria, as well as changes and stabilization of the intestinal microbiota and a decrease in microbial toxic metabolites in the intestine [3].

One of the current trends in the search for alternative substances is the development of new solutions for managing quorum sense in bacteria. Detection of bacterial quorum (QS) is a form of cell-to-cell communication that is vital to the pathogenicity of many bacteria and, therefore, a promising goal for the development of new treatment of microbial infections. Although many medicinal plants have antibacterial activity, it has been shown that only a few plants are aimed at determining quorum. QS inhibitors from medicinal plants are an upcoming trend for new antibacterial therapies.

Lamiaceae may be one of plant families that of interest in this regard. It is known that Lamiaceae substances exhibit antibacterial activity against gram-positive and gramnegative bacteria [4], antiangiogenic activity [5]. It is necessary to take into account that different phenolic composition and biological activity of the same representative of this family is possible, taking into account geographic growth [6]. Previously, a comparative study of the biological and antiquorum activity of this family was not performed for the Russian Federation.

\section{Material and methods}

The study was conducted in accordance with the Basic \& Clinical Pharmacology \& Toxicology policy for experimental and clinical studies [7].

\subsection{Plants and plant extracts}

Extracts of 4 medicinal plants of the Lamiáceae (Méntha piperíta, Sālvia officinālis, Oríganum vulgáre, Thymus serpýllum) at an initial concentration of $10 \mathrm{mg} / \mathrm{ml}$ were used as test substances. The action of substances was studied in a wide range of concentrations (from $10 \mathrm{mg} / \mathrm{ml}$ to $0.0097 \mathrm{mg} / \mathrm{ml}$ ).

Extracts were obtained from dry crushed plant material. Preparing aqueous extracts, 50 $\mathrm{ml}$ of hot sterile distilled water was added to $6 \mathrm{~g}$ of each sample and, depending on the structure of the plant material, boiled in a water bath for either 15 minutes (leaves, flowers) or 30 minutes (rhizomes, bark). The primary aqueous extracts were centrifuged at 1000 rpm within 10 minutes to remove solid particles, after it supernatants were collected and filtered through a syringe filter (Membrane Solutions LLC, USA) with a pore size of 0.4 $\mu \mathrm{m}$. Ethanol extracts were obtained by infusing $3 \mathrm{~g}$ of dry plant powder in $25 \mathrm{ml}$ of $45 \%$ ethanol for 24 hours at room temperature, centrifuged, and filtered as described above. The final samples were dried at $60^{\circ} \mathrm{C}$ and stored at $4^{\circ} \mathrm{C}$.

\subsection{Methods of bioluminescent analysis on E.coli MG1655}

The recombinant E.coli MG1655 based on parental cells transformed with pXen7 plasmid and with a constitutive type of luminescence was used as an object of study. It allows one to estimate the toxic effect of the studied substances by the nature of bioluminescence. In both cases, these vectors contain luxCDABE genes of natural luminous bacterium Photorhadus luminescens.

The used strain was cultured for 24 hours on LB agar (according to Muller) at $37^{\circ} \mathrm{C}$, $100 \mu \mathrm{g} / \mathrm{ml}$ ampicillin was added to the medium, it is a selective factor. Then, the cells were 
suspended in $0.9 \% \mathrm{NaCl}$ solution to an optical density of 0.5 relative units at $450 \mathrm{~nm}$, while measurements were carried out in transparent plastic wells of AIFR-01 UNIPLAN Immunoassay Analyzer by PIKON, Russia. After that, $500 \mu$ of the final bacterial suspension of E. coli MG1655 with the plasmid pXen7 was added to $1000 \mu$ of LB-broth without additional ongrowing.

To study the effect of the analyzed substances, tenfold dilutions of plant extracts were prepared in white opaque wells at a final concentration from $10 \mathrm{mg} / \mathrm{ml}$ to $0.0097 \mathrm{mg} / \mathrm{ml}$. After that, diluted solutions of extracts in a volume of $50 \mu \mathrm{l}$ were added to the test wells, and $50 \mu \mathrm{l}$ of water were added to the control wells, after which $50 \mu \mathrm{l}$ of the prepared strain suspension and $100 \mu \mathrm{l}$ of LB-broth were added to all samples.

Next, the microplate was placed in the measuring unit of luminometer Infinite $\AA 200$, "Tecan" (Austria). The measurement was carried out in the kinetic mode for 120 minutes at $37^{\circ} \mathrm{C}$. The experiments were performed at least in five repetitions.

The obtained results were initially processed using the Magellan TM luminometer software, the obtained data was further processed using the Excel 2010 computer program (Microsoft Inc.).

\subsection{C. violaceum ATCC 31532 Strain}

Chromobacterium violaceum ATCC 31532 (C. violaceum) is a natural isolate with a full cviI-cviR system that controls the formation of blue-violet pigment violacein available for visual and hardware recording with an absorption maximum at 570-600 nm. The QS system of the first type consists of the cviI gene (a functional analogue of the luxI gene) encoding an autoinductor synthase - N-hexanoyl lactone homoserine (C6-AHL); as well as the cviR gene (luxR analogue) encoding a receptor protein with the function of a transcriptional regulator.

\subsection{The study of the anti-QS activity of extracts of medicinal plants on C. violaceum ATCC 31532}

For biological analyses, extract samples were dissolved in sterile distilled water. Conducting an experimental series aimed at characterizing the anti-QS activity of each used substance, two-fold dilutions of dry extracts (in the concentration range of $0.078-10 \mathrm{mg} / \mathrm{ml}$ ) in distilled water were prepared in cells of a 96-well transparent plastic plate, mixed with equal volumes of LB-broth (Sigma, USA).

\subsection{Statistical processing of research results}

All experiments were performed at least in five repetitions. The obtained results were processed by variation statistics in Excel for Windows 10 and the program "Statistica 10 RU". To determine the nature of interaction in the compounds in the composition of the proposed compositions, an isobolographic analysis was used [11], conducted on the basis of a comparison of EC50 values.

\section{Resuts}

\subsection{The results of bioluminescent testing extract Méntha piperíta}

An analysis of the bioluminescent testing of Méntha piperita showed no toxic effect throughout the entire record period over the entire concentration range. We noticed a slight 
decrease in the luminescence of biosensor during the first 50 minutes, however, later the luminescence recovers, with lower concentrations of the analyte $(0.625 \mathrm{mg} / \mathrm{ml}-0.0097 \mathrm{mg}$ $/ \mathrm{ml}$ ) causing a slight induction of the lux operon (Fig. 1).

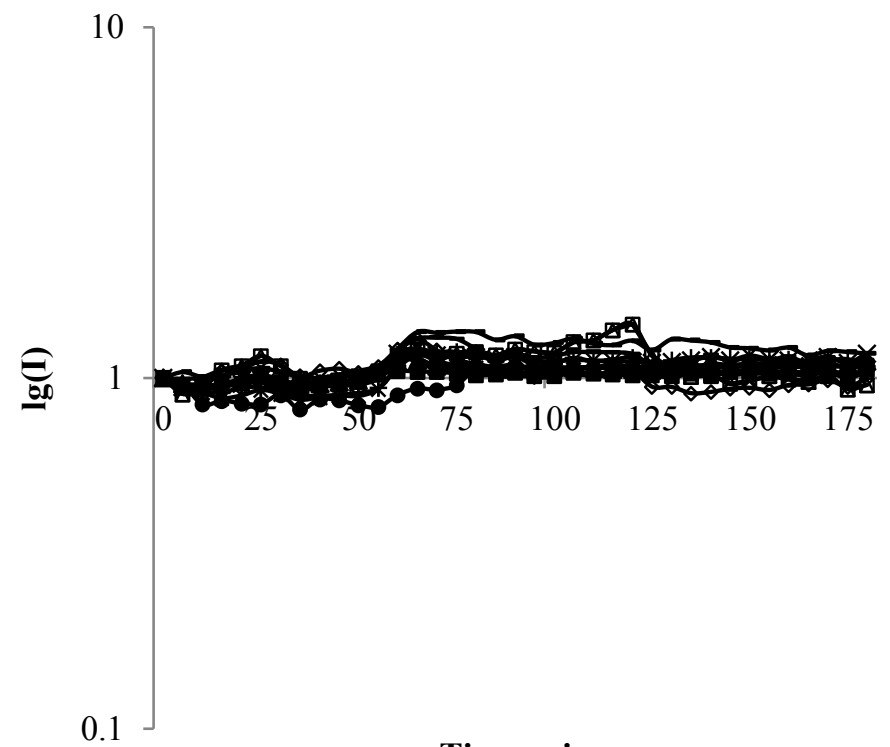

Time, min

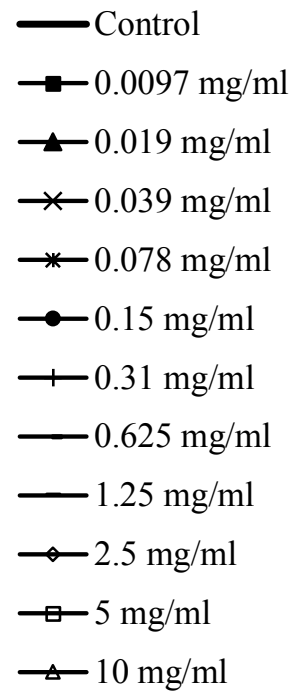

Fig.1. Kinetics of normalized bioluminescence of E. coli K12 TG1 strain with cloned luxCDABE genes of P. leiongnathi 54D10 ("Ecolum") upon contact with Méntha piperita extract.

EC50 calculation confirms all the above mentioned. None of the analyzed concentrations of the Méntha piperíta extract caused death of $50 \%$ bacterial cells, either during intermediate recording (60 minutes) or after 180 minutes of incubation. A slight decrease in luminescence of no more than $10 \%$ is observed only at a concentration of 10 $\mathrm{mg} / \mathrm{ml}$ after one hour of incubation, however as time passed the luminescence level not only restores, but also slightly increases.

There is information in the literature [8] that methanol, ethanol, and hexane extracts of other mint species - Mentha spicata and Mentha arvensis L. showed antibacterial activity against E. coli, in contrast to aqueous extract. This fact is consistent with the results of our research and indicates the need for additional research.

The prospects of research in this direction is confirmed by the recent research results on Mentha mozaffarianii [9], it revealed low toxicity after the subchronic introduction of plant oil to laboratory animals at a dose of $100 \mathrm{mg} / \mathrm{kg}$. It should be noted that toxicity may be seasonal in nature and depends on the species and part of the plant from which they are extracted, and the place of collection [10].

\subsection{The results of bioluminescent testing of Sālvia officinālis extract}

An analysis of the bioluminescent testing of Sālvia officinālis extract showed a slight antibacterial effect on the tested strain. The dependence of analyte concentration on biosensor inhibition should be noted (Fig. 2). Thus, a pronounced effect is observed at a concentration of $10 \mathrm{mg} / \mathrm{ml}$. The effect is achieved after $50-60$ minutes of contact of microbial cells with components of Sālvia officinālis extract and persists until the end of the analyzed period of time (180 minutes). Concentrations of substances from $5 \mathrm{mg} / \mathrm{ml}$ to 
$0.31 \mathrm{mg} / \mathrm{ml}$ also have a negative effect on cells of the test strain, however, a similar reaction is observed after 100 minutes of contact up to the end of the accounting time period. Further dilution of analyte $(0.15 \mathrm{mg} / \mathrm{ml}-0.0097 \mathrm{mg} / \mathrm{ml})$ caused a slight decrease in biosensor luminescence (no more than 10\%), it can be noted as a slightly toxic substance.

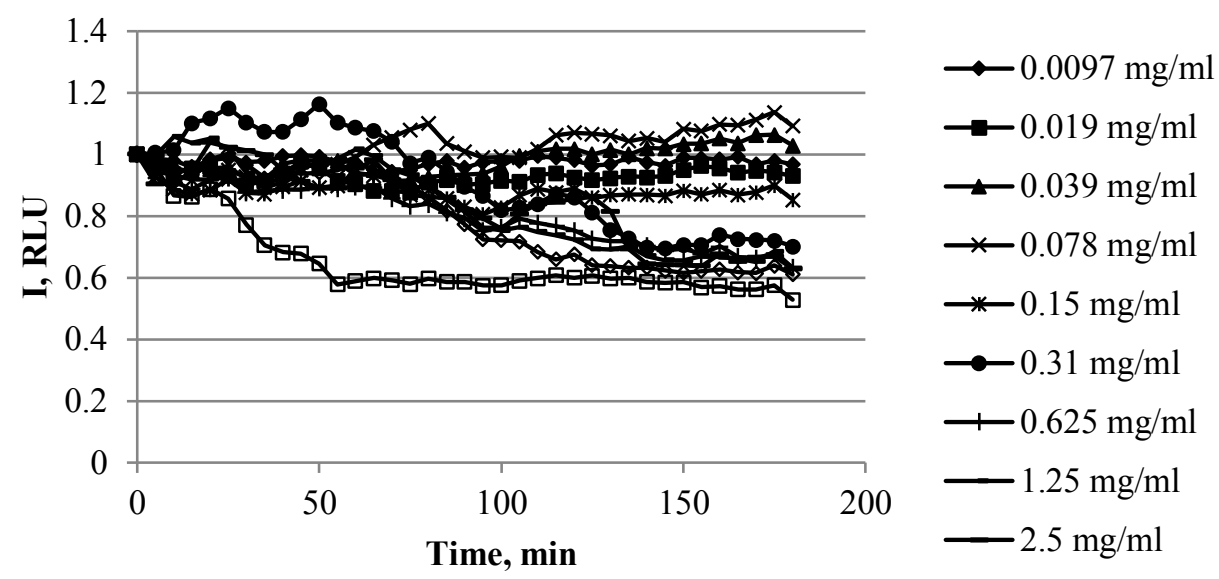

Fig.2. Dependence of normalized luminescence of E. coli K12 TG1 with cloned luxCDABE genes of P. leiongnathi 54D10 ("Ecolum") on the concentration of Sālvia officinālis extract.

The calculation of the EC50 showed that 50\% cell death was observed at a concentration of $10 \mathrm{mg} / \mathrm{ml}$, and $20 \%$ (EC20) was observed at a concentration of $0.15 \mathrm{mg}$ $/ \mathrm{ml}$. This dilution can be noted as slightly toxic, a further decrease in concentration did not lead to cell death, which can be regarded as non-toxic. Based on this, it can be assumed that an increase in the concentration above $10 \mathrm{mg} / \mathrm{ml}$ will provide a more pronounced antibacterial effect.

At the same time, some researchers using samples of another species (Salvia miltiorrhizae) from different places of China also noted a strong antibacterial effect on E. coli at a dose of $10 \mathrm{mg} / \mathrm{ml}$ [11] and above $125 \mu \mathrm{g} / \mathrm{ml}$ for Salvia officinalis [12]. At the same time, methanol and aqueous extracts of Salvia pachyphylla were inactive against E. coli, as well as the essential oils from Salvia dolomitica and Salvia somalensis.

\subsection{The results of bioluminescent testing of Oríganum vulgáre extract}

An analysis of the bioluminescent testing of Origanum vulgáre extract showed a decrease in the level of luminescence by $30 \%$ under the action of the analyte at a concentration of 10 $\mathrm{mg} / \mathrm{ml}$. At a concentration of $5-2.5 \mathrm{mg} / \mathrm{ml}$, a slight decrease in the level of bioluminescence is observed $(2-4 \%)$, further dilution of the substance did not cause an inhibitory effect, and fully corresponded to the control values and even slightly exceeded them (Fig.3). 


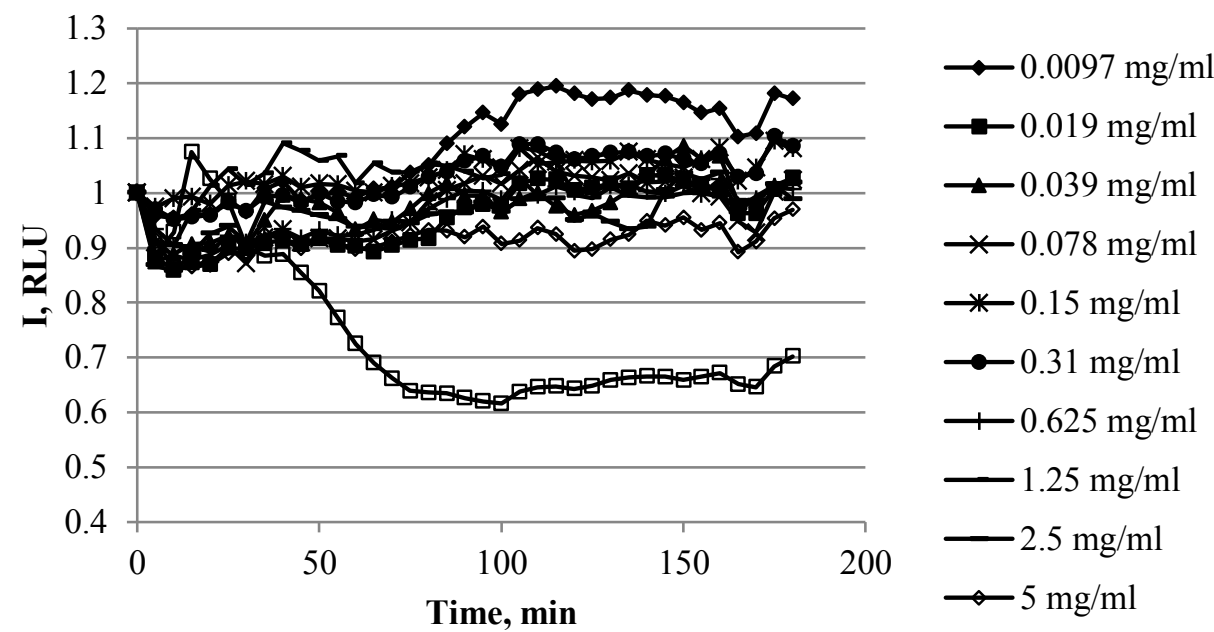

Fig. 3. Dependence of normalized luminescence of E. coli K12 TG1 strain with cloned luxCDABEgenes of P. leiongnathi 54D10 ("Ecolum") on the concentration of Oríganum vulgáre extract.

The calculation of the EC50 parameter also revealed no threshold concentrations that cause $50 \%$ suppression of luminescence or more. Based on this, it can be concluded that Oríganum vulgáre extract does not have a pronounced toxic effect.

There is evidence that Origanum vulgare and Origanum heracleoticum essential oils are effective against E. coli strains. At the same time, O. syriacum and O. ehrenbergii showed moderate antimicrobial activity with minimal inhibitory concentrations at doses ranging from 400 to $1200 \mathrm{~g} / \mathrm{ml}$, which is also close to the results of our studies.

\subsection{The results of bioluminescent testing of Thýmus serpýllum}

Analysis of the results of bioluminescent testing of Thýmus serpýllum extract showed a pronounced antibacterial effect on the test organism (Fig. 4). So, at a maximum concentration of $10 \mathrm{mg} / \mathrm{ml}, 50 \%$ inhibition of luminescence is observed, which can be defined as the EC50 parameter. Accordingly, an increase in the concentration more than stated above may have a pronounced toxic effect.

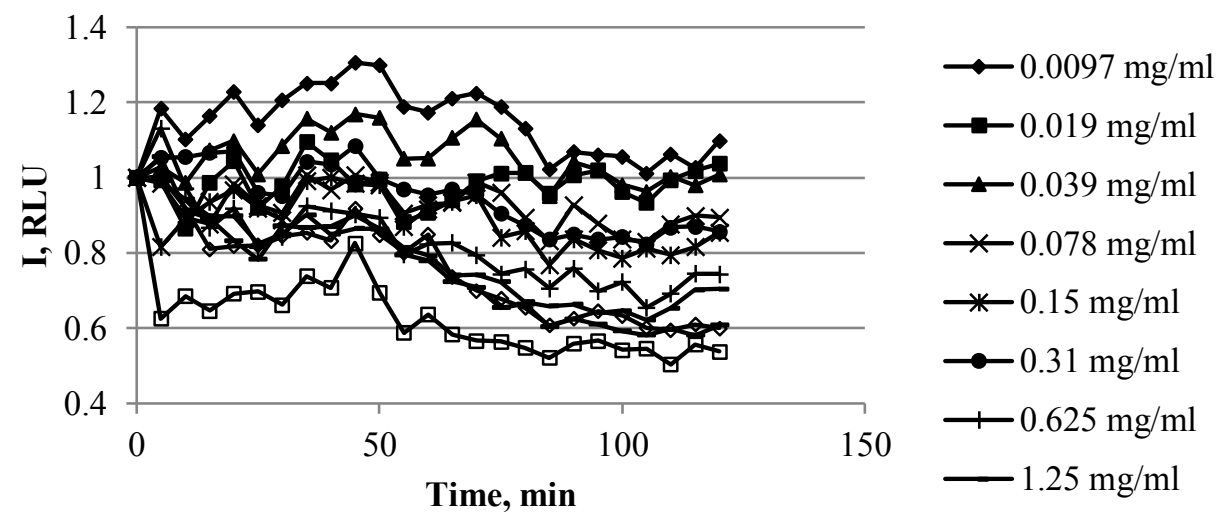

Fig.4. Dependence of normalized luminescence of $E$. coli K12 TG1 strain with cloned luxCDABE genes of $P$. leiongnathi 54D10 ("Ecolum") on the concentration of Thymus serpýllum extract. 
Further dilution of substance reduced the biosensor quenching from $40 \%$ at $5 \mathrm{mg} / \mathrm{ml}$ to $10 \%$ at $0.78 \mathrm{mg} / \mathrm{ml}$, respectively. Less concentrated solutions did not cause inhibition of luminescence of the test strain and did not differ from the control values. Thus, you can determine the extract of Thýmus serpýllum as a moderately toxic substance.

There is an evidence that the aqueous extract of Thymus vulgaris did not show antibacterial activity against E. coli [8], in contrast to the results of our research. This effect is probably due to the fact that the extract can be saturated with phenols and flavonoids (Thymus kotschyanus) [9], as a result, the extracts show moderate antibacterial activity against gram-negative and gram-positive bacteria [10].

\section{Conclusion}

The obtained results indicated a low growth-inhibitory activity of all the studied extracts $(\mathrm{MIC100}=10 \mathrm{mg} / \mathrm{ml})$. At the same time, it was found that all the tested compounds in subinhibitory concentrations suppressed the quorum-dependent biosynthesis of violacein, although the effect was mild $(\mathrm{EC} 100=10 \mathrm{mg} / \mathrm{ml})$ and had some differences. Thus, the MIC50/EC50 ratio, most fully characterizing the range of concentrations of plant extracts that cause suppression of violacein quorum-dependent biosynthesis in the absence of a growth-inhibiting effect, increased in the series: Méntha piperíta $(\mathrm{EC} 50=1.13) \rightarrow$ Sālvia officinālis $($ EC50 = 1.16) $\rightarrow$ Oríganum vulgáre $($ EC50 = 1.59) $\rightarrow$ Thýmus serpýllum (EC50 $=1.88$ ).

With respect to Méntha, the evidence has been earlier obtained that Mentha suaveolens acts as an inhibitor of violacein production and biofilm formation [5]. The ability of Mentha piperita to interfere with QS systems of various gram-negative pathogens containing different AHL molecules was also evaluated, and the AHL-dependent production of violacein reduced [6]. In addition, it was previously noted that the essential oils of Thymus daenensis and Origanum vulgare [7, 8] affect the perception of the quorum of Streptococcus pneumoniae and the formation of a biofilm.

Using the models of E. coli MG1655 and Chromobacterium violaceum ATCC 31532, a comparative assessment of water extracts of plants of the Lamiaceae family growing in the Russian Federation was carried out as stated above. Extracts of Oríganum vulgáre and Thýmus serpýllum showed a pronounced antibacterial effect. The results indicate a slight growth-inhibiting and weakly expressed quorum-inhibiting activity, increasing in the series Méntha piperíta $\rightarrow$ Sālvia officinālis $\rightarrow$ Oríganum vulgáre $\rightarrow$ Thýmus serpýllum. Based on the results obtained, further chromatographic evaluation of plant extracts is necessary in order to identify active biological substances, to conduct a more extended study using various solvents. The prospects of research are supported by the facts that Thymus vulgaris L. and Origanum vulgare L. were identified as the best candidates for modulating the immune system [9].

\section{Acknowledgement}

Research was performed in the framework of project No. 0526-2019-0002 and with financial support from the Russian Science Foundation (16-16-10048)

\section{References}

1 E. Sheyda, O. Sipaylova, O. Kvan, S. Notova, D. Nesterov, E. Rusakova, D. Kosyan, G. Duskaev, Life Science Journal, 11 (9), 25, 180-184. (2014) 
2 G.K. Duskaev, D.G. Deryabin, I.F. Karimov, D.B. Kosyan, S.V. Notova, Journal of Pharmaceutical Sciences and Research, 10 (1), 91-95. (2018)

3 P. Tveden-Nyborg, T.K. Bergmann, J. Lykkesfeld, Basic Clin Pharmacol Toxicol 123(3), 233-235 (2018). DOI: 10.1111/bcpt.13059

4 A. Qadir, A. Ali, M. Arif, A.H. Al-Rohaimi, S.P. Singh, U. Ahmad, Fatty Oil Components 68(6), 344-348 (2018). DOI: 10.1055/s-0043-123466

5 M.P. Melo, R.P. Fernandes, M.A. Trindade, F.G. Tonin, C.G. Lima, S.M. Pugine, J Food Sci Technol 53(1), 451-460 (2015). DOI: 10.1007/s13197-015-1994-x

6 I. Cocan, E. Alexa, C. Danciu, I. Radulov, A. Galuscan, D. Obistioiu, Exp Ther Med 15(2), 1863-1870. (2018). DOI: 10.3892/etm.2017.5640

7 Q. Abdallah, I. Al-Deeb, A. Bader, F. Hamam, K. Saleh, A. Abdulmajid, Mol Med Rep 18(2), 2441-2448 (2018). DOI: 10.3892/mmr.2018.9155

8 C.A. Semeniuc, M.I. Socaciu, S.A. Socaci, V. Mureșan, M. Fogarasi, A.M. Rotar, Molecules 23(9), 2261 (2018). DOI: 10.3390/molecules23092261

9 M. Fournomiti, A. Kimbaris, I. Mantzourani, S. Plessas, I. Theodoridou, V. Papaemmanouil, et al., Microb Ecol Health Dis 26, 23289 (2015). DOI: 10.3402/mehd.v26.23289

10 G. Almada-Taylor, L. Díaz-Rubio, R. Salazar-Aranda, N. Waksman de Torres, C. Uranga-Solis, J. Delgadillo-Rodríguez, Plants (Basel) 7(4), 105 (2018). DOI: $10.3390 /$ plants7040105

11 K. Tzima, N.P. Brunton, D.K. Rai, Plants (Basel) 7(2), 25 (2018). DOI: 10.3390/plants7020025

12 A. Sharifi, A. Ahmadi, A. Mohammadzadeh, Acta Microbiol Immunol Hung 65(3), 345-359 (2018). DOI: 10.1556/030.65.2018.013 